\title{
Activation of Group II Metabotropic Glutamate Receptors in the Nucleus Accumbens Shell Attenuates Context-Induced Relapse to Heroin Seeking
}

\author{
Jennifer M Bossert*', Sarah M Gray', Lin Lu' and Yavin Shaham' \\ 'Behavioral Neuroscience Branch, Intramural Research Program, National Institute on Drug Abuse, NIHIDHHS, Baltimore, MD, USA
}

\begin{abstract}
Using a rat relapse model, we previously reported that re-exposing rats to a drug-associated context, following extinction of operant responding in a different context, reinstates heroin seeking. In an initial pharmacological characterization, we found that the $\mathrm{mGluR}_{2 / 3}$ agonist LY379268, which acts centrally to reduce evoked glutamate release, attenuates context-induced reinstatement of heroin seeking when injected systemically or into the ventral tegmental area, the cell body region of the mesolimbic dopamine system. Here, we tested whether injections of LY379268 into the nucleus accumbens (NAc), a terminal region of the mesolimbic dopamine system, would also attenuate context-induced reinstatement of heroin seeking. Rats were trained to self-administer heroin; drug infusions were paired with a discrete tone-light cue. Subsequently, lever pressing was extinguished in the presence of the discrete cue in a context that differed from the drug self-administration context in terms of visual, auditory, tactile, and circadian cues. After extinction of responding, LY379268 was injected to different groups of rats into the NAc core or shell or into the caudate-putamen, a terminal region of the nigrastriatal dopamine system. Injections of LY379268 into the NAc shell (0.3 or $1.0 \mu \mathrm{g})$ dose-dependently attenuated context-induced reinstatement of heroin seeking. Injections of $1.0 \mu \mathrm{g}$ of LY379268 into the NAc core had no effect, while a higher dose (3.0 $\mu \mathrm{g}$ ) decreased this reinstatement. Injections of LY379268 (3.0 $\mu \mathrm{g}) \quad 1.5 \mathrm{~mm}$ dorsal from the NAc core into the caudate-putamen were ineffective. Results suggest an important role of glutamate transmission in the NAc shell in context-induced reinstatement of heroin seeking.

Neuropsychopharmacology (2006) 31, 2197-2209. doi:I 0.1038/sj.npp. I 300977; published online 7 December 2005
\end{abstract}

Keywords: drug environment; extinction; nucleus accumbens core; opiate self-administration; reinstatement; relapse

\section{INTRODUCTION}

The seminal studies of Wikler (1973) and subsequent investigations (O'Brien et al, 1992) indicate that environmental stimuli previously associated with opiate intake can provoke relapse to drug use in humans. In laboratory animals, discrete conditioned stimuli (eg tone and light) that are explicitly paired with opiate injections (Schuster and Woods, 1968; Davis and Smith, 1976; Fuchs and See, 2002; Bossert et al, 2005) or discriminative stimuli (eg specific odors) that become predictors of opiate availability during discrimination training (McFarland and Ettenberg, 1997; Gracy et al, 2000) can reinstate opiate seeking after extinction of the drug-taking behavior in the absence of

*Correspondence: Dr JM Bossert, Behavioral Neuroscience Branch, IRP/NIDA/NIH, 5500 Nathan Shock Drive, Baltimore, MD 21224, USA, Tel: + | 4I0 550 1755, Fax: + | 410550 1612,

E-mail: jbossert@intra.nida.nih.gov

Received 18 August 2005; revised 3 October 2005; accepted 4 October 2005

Online publication: 20 October 2005 at http://www.acnp.org/citations/ Npp I02005050524/default.pdf these cues. However, despite evidence that exposure to environments previously associated with opiate intake can provoke drug relapse in humans (O'Brien et al, 1992), until recently the role of contextual stimuli (eg the physical characteristics of the drug environment, time of day) in preclinical models of drug relapse has been largely ignored (Shalev et al, 2002; Shaham et al, 2003). This issue is important for the understanding of processes underlying relapse to drugs of abuse because the environmental context can profoundly influence extinction and reinstatement of learned behaviors (Gunther et al, 1998; Bouton, 2002).

We adapted a 'renewal' procedure (Bouton and Bolles, 1979) to study the role of the environmental context in reinstatement of drug seeking. In the renewal procedure, conditioned responses to discrete stimuli are renewed (or reinstated) when they are reintroduced in the original conditioning context (where they were previously paired with the primary reinforcer) after extinction in a different context (Bouton and Swartzentruber, 1991). Using this procedure, we found that re-exposing rats to a drug-associated context, following extinction in a different context, reinstates cocaine, heroin, or speedball 
(a heroin-cocaine mixture) seeking (Crombag et al, 2002; Crombag and Shaham, 2002; Bossert et al, 2004).

In initial neuropharmacological characterization of context-induced reinstatement of heroin seeking (Bossert $e t$ al, 2004), we examined the effect of systemic and intra-ventral tegmental area (VTA) injections of the group II metabotropic glutamate receptor $\left(\mathrm{mGluR}_{2 / 3}\right)$ agonist LY379268, which acts centrally to reduce evoked glutamate release (Schoepp, 2001). Group II metabotropic glutamate receptors consist of the $\mathrm{mGluR}_{2}$ and the $\mathrm{mGluR}_{3}$ subtypes (Schoepp, 2001). $\mathrm{mGluR}_{2}$ are expressed primarily on presynaptic glutamate (and GABA) neurons, and when activated they provide negative feedback to decrease evoked neurotransmitter release (Anwyl, 1999; Schoepp, 2001). $\mathrm{mGluR}_{3}$ are expressed on both postsynaptic and presynaptic neurons and on glia, but their functional role is unknown (Schoepp, 2001; Tamaru et al, 2001). The VTA is the cell body region of the mesolimbic dopamine system and there is evidence that glutamate transmission in this brain area is involved in conditioned and unconditioned reinforcing effects of opiate drugs (Carlezon et al, 1997; Xi and Stein, 2002; Harris et al, 2004) and relapse to drug seeking, as measured in a reinstatement model (Vorel et al, 2001; Sun et al, 2005; Wang et al, 2005).

We found that systemic injections of LY379268 resulted in a dose-dependent decrease in context-induced reinstatement of heroin seeking; complete blockade of this reinstatement was observed at the highest dose tested (Bossert et al, 2004). On the other hand, the effect of intraVTA injections of LY379268 on context-induced reinstatement was not dose dependent and the drug only partially blocked this reinstatement. We also found that injections of LY379268 into the nearby substantia nigra, the cell body region of the nigrastriatal system, had no effect on contextinduced reinstatement of heroin seeking. The differences between the effects of systemic and intra-VTA injections of LY379268 suggest that, following systemic injections, the drug also acts in other brain sites.

In the present report, we studied the effect of injections of LY379268 into the nucleus accumbens (NAc), a terminal region of the mesolimbic dopamine system, on contextinduced reinstatement of heroin seeking. $\mathrm{mGluR}_{2}$ and mGluR $_{3}$ are expressed in the NAc (Ohishi et al, 1993a,b; Tamaru et al, 2001; Richards et al, 2005), and this brain area receives glutamatergic projections from the prefrontal cortex, thalamus, basolateral amygdala, and hippocampus (Brog et al, 1993; Heimer et al, 1997; Groenewegen et al, 1999b). Infusions of an $\mathrm{mGluR}_{2 / 3}$ agonist into the NAc decrease glutamate release (Xi et al, 2002). Intra-NAc injections of an AMPA receptor antagonist attenuate reinstatement of cocaine priming-induced reinstatement of drug seeking, (Cornish and Kalivas, 2000) while intra-NAc AMPA injections reinstate cocaine seeking (Cornish and Kalivas, 2000; Suto et al, 2004). There is also evidence that glutamate transmission in the NAc is involved in conditioned drug effects. Blockade of NAc AMPA/kainate receptors attenuates conditioned place preference induced by morphine, cocaine, or amphetamine (Layer et al, 1993; Kaddis et al, 1995) and exposure to environmental cues previously paired with cocaine injections increases glutamate release in the NAc (Hotsenpiller et al, 2001).
In the studies reviewed above, however, the distinct roles of the two main subdivisions of the NAc, the core and shell (Groenewegen et al, 1987; Heimer et al, 1991), were not assessed. This anatomical distinction is important because there are reports that NAc core and shell differentially modulate the conditioned and unconditioned behavioral effects of opiate and psychostimulant drugs (Everitt and Wolf, 2002; Di Chiara et al, 2004; Ikemoto and Wise, 2004). For example, reversible or permanent lesions of the NAc core, but not the shell, attenuate cue-controlled cocaine seeking, as measured by the second-order schedule and the cue-induced reinstatement procedures (Fuchs et al, 2004; Ito et al, 2004); see also Di Ciano and Everitt (2001) and Hyytia and Backstrom (2005) for similar findings with ionotropic glutamate receptor antagonists. On the other hand, 6-OHDA lesions of the NAc shell, but not the core, attenuate the reinforcing effects of amphetamine, as measured in the conditioned place preference procedure (Sellings and Clarke, 2003). Based on these findings, we determined whether injections of LY379268 into the NAc core or shell would attenuate context-induced reinstatement of heroin seeking. We also studied the effect of LY379268 on context-induced reinstatement after injections into the nearby caudate-putamen, a terminal region of the nigrastriatal dopamine system. The caudate-putamen is known to be involved in stimulus-response learning (Everitt $e t a l$, 2001; White and McDonald, 2002), and data from two studies indicate that both dopamine and glutamate in this brain area are involved in cue-controlled cocaine seeking (Ito et al, 2002; Vanderschuren et al, 2005). Additionally, we tested the effect of injections of LY379268 into the NAc core or shell on high rates of lever responding for sucrose in order to rule out the possibility that these injections decrease context-induced reinstatement due to their motor impairing effects on lever pressing.

\section{MATERIALS AND METHODS}

\section{Subjects}

Male Long-Evans rats (Charles River, $n=129$ ), weighing $300-400 \mathrm{~g}$ were used. After surgery, the rats were housed individually in the animal facility under a reverse 12 -h light-dark cycle (lights off at 0900). Food and water were freely available in the rats' home cage throughout the experiment. Experimental procedures followed the guidelines of the 'Principles of Laboratory Animal Care' (NIH publication no. $86-23,1996)$. Of the 129 subjects, 50 were excluded due to catheter failure $(n=13)$, failure to learn to self-administer heroin $(n=2)$, poor health $(n=11)$, misplaced or blocked cannulae $(n=9)$, failure to meet an extinction criterion of 25 responses per $3 \mathrm{~h}(n=9)$, or abnormally high rates of responding in the extinction context ( $>5$ SD from the group mean) during testing $(n=6)$, potentially due to the stress associated with the injection procedure.

\section{Intracranial and Intravenous Surgery}

Rats were anesthetized with mixtures of either xylazine and ketamine ( 5 and $50 \mathrm{mg} / \mathrm{kg}$, i.p. ) or sodium pentobarbital and chloral hydrate (60 and $25 \mathrm{mg} / \mathrm{kg}$, i.p.), and permanent 
guide cannulae (23-gauge, Plastics One, Roanoke, VA) were implanted bilaterally $1 \mathrm{~mm}$ above the NAc core, shell or caudate-putamen. The coordinates (Paxinos and Watson, $2005)$ for the NAc core $\left(6^{\circ}\right.$ angle aimed medially) were AP + $1.6, \mathrm{ML} \pm 2.5$, and DV -6.0 ; coordinates for the NAc shell $\left(6^{\circ}\right.$ angle aimed medially) were $\mathrm{AP}+1.6, \mathrm{ML} \pm 1.7$, and $\mathrm{DV}-6.5$; coordinates for the caudate-putamen $\left(6^{\circ}\right.$ angle aimed medially) were $\mathrm{AP}+1.6, \mathrm{ML} \pm 2.5$, and $\mathrm{DV}-4.5$. Following cannulae implantation, silastic catheters were inserted into the jugular vein and were passed subcutaneously to the top of the skull, as described previously (Highfield et al, 2000; Shaham et al, 2000b). The catheters were then attached to a modified 22-gauge cannula (Plastics One, Roanoke, VA) and mounted to the rat's skull with dental cement. Buprenorphine $(0.1 \mathrm{mg} / \mathrm{kg}$, s.c.) was given after surgery and rats were allowed to recover for 7-10 days before behavioral testing began. During the recovery and training phases, catheters were flushed every $24-48 \mathrm{~h}$ with sterile saline. For Experiment 2 (sucrose self-administration), the rats were bilaterally implanted with cannulae aimed at the NAc core or NAc shell and were allowed 7 days to recover before behavioral testing began.

\section{Intracranial Injections}

Bilateral intracranial injections of LY379268 (a gift from Eli Lilly) were made using a syringe pump (Harvard Appartus Inc., Holliston, MA) and $10-\mu 1$ Hamilton syringes (Hamilton Co., Reno, NV) that were connected via polyethylene-50 tubing to 30-gauge injectors (Plastics One). LY379268 (0.3, 1.0 , and $3.0 \mu \mathrm{g})$ infusions $(0.5 \mu \mathrm{l})$ were made over $1 \mathrm{~min}$ and the injectors were left in place for $1 \mathrm{~min}$. The rats were tested 5-10 min after the bilateral injections of LY379268. After testing, the rats were deeply anesthetized, after which they were decapitated and the brains were removed. Coronal sections $(40 \mu \mathrm{m})$ were sliced on a cryostat and were stained with Cresyl Violet (ICN Biomedicals Inc., Aurora, $\mathrm{OH}$ ) and brains were verified for cannulae placement.

\section{Apparatus}

Rats were trained and tested in standard operant chambers $\left(25 \times 27 \times 30 \mathrm{~cm}^{3}\right)$ located inside sound-attenuating cabinets (Med Associates, Georgia, VT). Each chamber was equipped with two levers located $9 \mathrm{~cm}$ above the grid floor. Responding on one lever, the active retractable lever, activated the infusion pump (Razel, Stamford, CT) while responding on the inactive (nonretractable) lever was recorded, but had no programmed consequences. The two contexts differed from each other in terms of session onset time (0900 or 1500) and types of background stimuli. In one context, the sound-attenuating cabinet doors were closed, the white houselight was turned off, a ventilation fan within the sound-attenuating cabinets was programmed to turn on at the start of each session, the floor consisted of 23 stainless-steel rods $(3.2 \mathrm{~mm}$ in diameter) spaced $9.4 \mathrm{~mm}$ apart, and there were holes in the panels located adjacent to the active lever. In the other context, the sound-attenuating cabinet doors were open, a white houselight was turned on at the onset of the session, the ventilation fan was turned off, the floor consisted of 19 stainless-steel rods $(4.8 \mathrm{~mm}$ in diameter) spaced $10.8 \mathrm{~mm}$ apart, and an empty feeder and water bottle were located on the front door. Thus, the two contexts differed in their tactile, visual, auditory, and circadian cues. The contexts are referred to as A and B, whereby $A$ is the self-administration context and $B$ is the extinction context. The physical environments that provided Contexts A and B were counterbalanced.

\section{Drugs}

LY379268 $(0.3,1.0$, and $3.0 \mu \mathrm{g})$ was dissolved in $1.2 \mathrm{M} \mathrm{NaOH}$ solution (pH adjusted to 7.4) (Kim and Vezina, 2002; Kim et al, 2005). The bilateral intracranial doses of LY379268 were based on our previous report (Bossert et al, 2004). Heroin $\mathrm{HCl}$ (a gift from NIDA) was dissolved in sterile saline and was self-administered at unit doses of 0.1 or $0.05 \mathrm{mg} / \mathrm{kg}$.

\section{Procedures}

Experiment 1: effect of intracranial injections of LY379268 on context-induced reinstatement. The experiments consisted of three phases: self-administration training (12 days), extinction training (13-27 days), and tests for the effect of intracranial LY379268 injections on contextinduced reinstatement of heroin seeking (2 days). The contexts are labeled as Context A (heroin self-administration environment) and Context $B$ (non-heroin environment) and the experimental sequence was $\mathrm{A}$ (training) - $\mathrm{B}$ (extinction) - A (testing).

Training and extinction: Rats were trained to selfadminister heroin $\mathrm{HCl}$ for 3-h/day for 12 days under a fixed-ratio-1 schedule. Heroin (diacetylmorphine $\mathrm{HCl}$; NIDA) was dissolved in sterile saline and infused at a volume of $65 \mu \mathrm{l}$ over $2.3 \mathrm{~s}$ at a dose of 0.1. (first six sessions) and 0.05 (last six sessions) $\mathrm{mg} / \mathrm{kg} /$ injection. The heroin training doses are based on previous studies (Shaham et al, 2000a; Bossert et al, 2004) and the unit dose was halved after the 6th day of training in order to verify that the rats reliably acquired drug self-administration, as indicated by the increase in lever responding for the lower dose (Yokel, 1987). During training, heroin infusions were earned under a fixed-ratio-1 (2.3 s timeout) reinforcement schedule and were accompanied by a compound tone $(2900 \mathrm{~Hz}, 20 \mathrm{~dB}$ above background)-light (a 7.5-W white light located above the active lever) cue for $2.3 \mathrm{~s}$. Sessions began with the introduction of the tone-light cue for $2.3 \mathrm{~s}$ and the insertion of the active lever. Depending on the context, either the houselight was illuminated or the ventilation fan was turned on. At the end of each session, the lights and fans were turned off, the active lever retracted, and the rats were returned to the animal colony room. During the extinction phase, the procedures were identical to those of training, except that the drug syringes were removed and extinction occurred in a different (non-drug) context (Context B). Rats that did not meet an extinction criterion $(\leqslant 25$ active lever responses during the last three extinction sessions) were excluded. The data reported here were collected over a period of 14 months; in the initial two runs, the rats were tested after 13-17 extinction days; however, because in subsequent runs a number of the rats did not meet the 
extinction criterion within this time period, the number of extinction sessions was extended for up to 27 sessions.

Tests for reinstatement: Tests started after a minimum of 13 daily extinction sessions and consisted of two sessions. In the two counterbalanced test sessions, the rats were pretreated with vehicle or LY379268 prior to exposure to the training context (A) or the extinction context (B). The tests were performed $48 \mathrm{~h}$ apart. Eight groups of rats $(n=7-10)$ were used. LY379268 was injected intracranially into the NAc core $(0,1.0$, or $3.0 \mu \mathrm{g}$; three groups), the NAc shell $(0,0.3$, or $1.0 \mu \mathrm{g}$; three groups), or the caudate-putamen ( 0 or $3.0 \mu \mathrm{g}$; two groups). For each brain area, the experimental design included the between-subject factor of LY379268 Dose and the within-subjects factor of Test Context (Training (A) or Extinction (B)). Thus, each rat was injected in both the training and the extinction contexts with either the vehicle or one dose of LY379268.

Experiment 2: effect of intracranial injections of LY379268 on lever responding for sucrose. This experiment consisted of two phases: sucrose self-administration training (15 days) and tests for the effects of intracranial LY379268 or vehicle injections on sucrose self-administration (5 days).

Training: At 6 days after surgery, the rats were transported to the self-administration chambers where they were chronically housed. During training (and testing) food was restricted to maintain $85-90 \%$ of the rats' free-feeding weight ( $\sim 20 \mathrm{~g}$ of food/day). For the first $24 \mathrm{~h}$ in the selfadministration chambers and prior to training, the rats had free access to the $5 \%$ sucrose solution in their water bottles. The rats were then given two 3 -h autoshaping sessions in which $0.2 \mathrm{ml}$ of $5 \%$ sucrose was infused into the liquid receptacles every $2 \mathrm{~min}$ on average. Following autoshaping, the rats were trained to self-administer the $5 \%$ sucrose solution ( $0.2 \mathrm{ml} /$ reward delivery) for 15 days. Sucrose rewards were earned under a fixed-ratio-1 (8-s timeout) reinforcement schedule and were accompanied by a compound tone $(2900 \mathrm{~Hz}, 20 \mathrm{~dB}$ above background)-light (a 7.5-W white light located above the active lever) cue for $4 \mathrm{~s}$. The self-administration sessions were for $3 \mathrm{~h} /$ day during the first 6 days and for $1 \mathrm{~h} /$ day during the remaining 9 days. During training, the number of sucrose deliveries was limited to $200 /$ session in order to prevent the rats from emptying the $60-\mathrm{ml}$ syringes in the middle of the daily sessions.

Injections of LY379268: When rats displayed stable responding ( $<10 \%$ variability over 3 days), the effect of LY379268 on sucrose self-administration was examined. A within-subjects design was used for the injections of the vehicle and LY379268. Vehicle and LY379268 were injected 5-10 min prior to the 1 -h self-administration session, the order of the injections was counterbalanced, and injections were given every $48 \mathrm{~h}$. Vehicle and LY379268 were injected bilaterally into the NAc shell $(n=5 ; 0.3$ and $1.0 \mu \mathrm{g})$ or into the NAc core $(n=7 ; 1.0$ and $3 \mu \mathrm{g})$. The intracranial doses of LY379268 for the NAc core and shell were the same as those used in Experiment 1.

\section{Statistical Analyses}

Data from Experiment 1 were analyzed separately for total (non-reinforced) active and inactive lever responses using a mixed factorial design in which the between-subjects factor is LY379268 Dose and the within-subjects factor is Test Context (Training (A) or Extinction (B)). Post hoc Fisher PLSD tests (two-tailed) were performed following significant interaction effects. The groups of rats tested with different doses of LY379268 had similar mean number of lever presses during the training and extinction phases. Thus, the nonsignificant group differences during these phases are not reported. Data from Experiment 2 were analyzed for active lever responses with ANOVA using the repeated-measures factor of LY379268 Dose.

\section{RESULTS}

\section{Experiment 1: Effect of Intracranial Injections of LY379268 on Context-Induced Reinstatement}

Training and extinction. Figures 1a, 2a, and 3a show the mean \pm SEM number of heroin infusions and responses on the active and inactive levers for rats subsequently tested for the effect of LY379268 injections into the NAc shell and core and the caudate-putamen, respectively. The rats demonstrated reliable heroin self-administration, as indicated by the increase in lever responding when the heroin dose was decreased from 0.1 to $0.05 \mathrm{mg} / \mathrm{kg} /$ infusion. Figures $1 \mathrm{~b}, 2 \mathrm{~b}$ and $3 \mathrm{~b}$ show the mean \pm SEM number of responses on the previously active and inactive levers during the first 13 extinction sessions for these rats. As expected, during the extinction phase, response rates decreased over days.

\section{Tests for Reinstatement}

NAc shell. Intra-NAc shell injections of LY379268 attenuated lever responding when rats were exposed to the training context after extinction in the different context; LY379268 had no effect on active lever responding in the extinction context or on inactive lever responding in the training or the extinction context (Figure 1c and $d$ ). Statistical analysis revealed significant main effects for active lever responding for Test Context $\left(\mathrm{F}_{(1,22)}=55.8\right.$, $p<0.01)$ and LY379268 Dose $\left(\mathrm{F}_{(2,22)}=11.9, p<0.01\right)$ and a significant interaction for LY379268 Dose by Test Context $\left(\mathrm{F}_{(2,22)}=11.1, p<0.01\right)$. No significant effects were observed for inactive lever responding ( $p$-values $>0.05)$. Post hoc group differences are indicated in Figure 1c.

NAc core. Intra-NAc core injections of the high, but not the lower dose of LY379268 attenuated lever responding when rats were exposed to the training context after extinction in the different context (Figure 2c); LY379268 had no effect on active lever responding in the extinction context or on inactive lever responding in the extinction or the training context (Figure 2d). Statistical analysis revealed significant main effects for active lever responding for Test Context $\left(\mathrm{F}_{(1,26)}=83.9, p<0.01\right)$ and LY379268 Dose $\left(\mathrm{F}_{(2,26)}=5.6\right.$, $p<0.01)$ and a significant interaction for LY379268 Dose by Test Context $\left(\mathrm{F}_{(2,26)}=6.7, p<0.01\right)$. The analysis of inactive lever responding revealed a significant effect of Test 

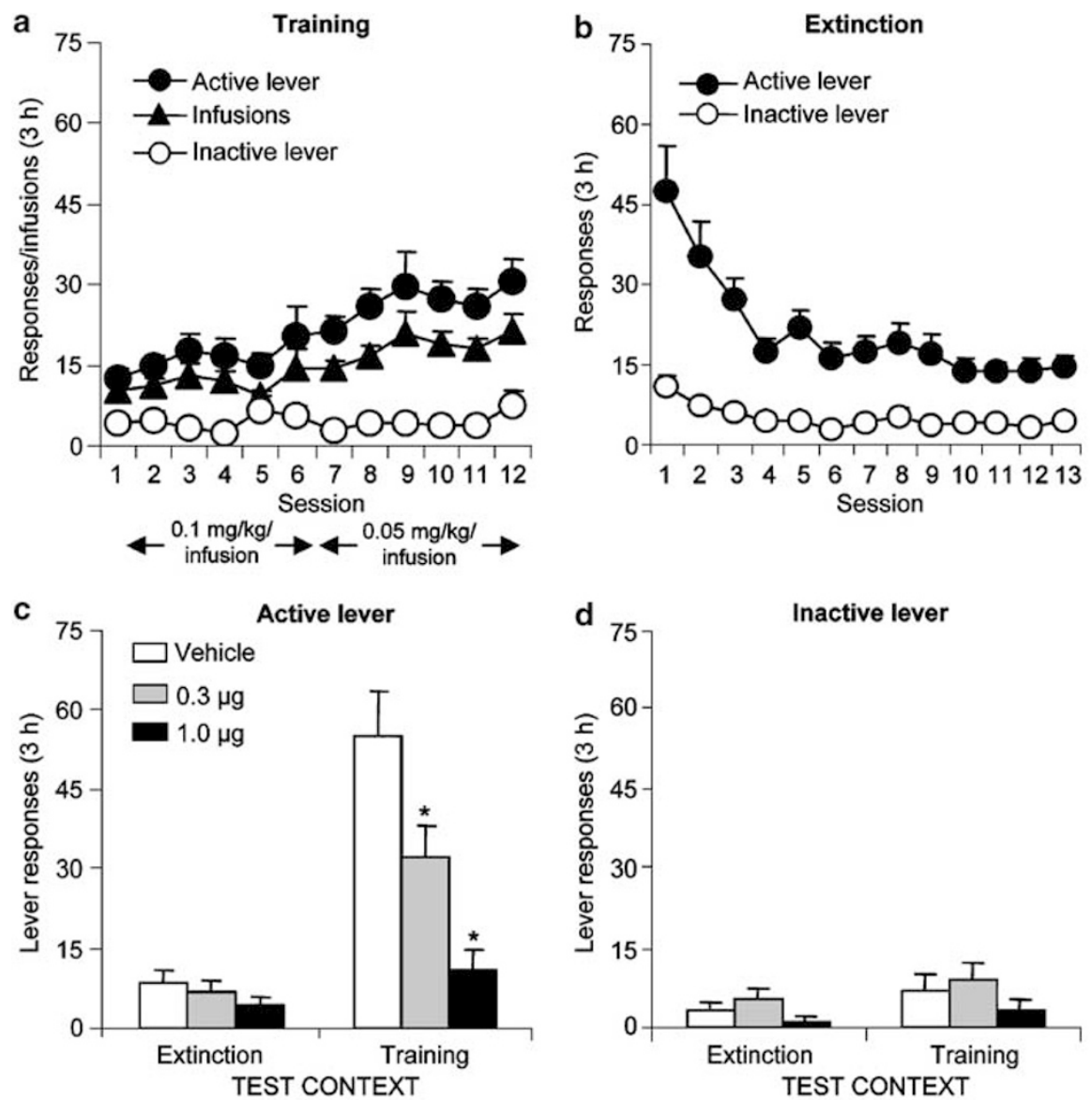

e Cannula placement
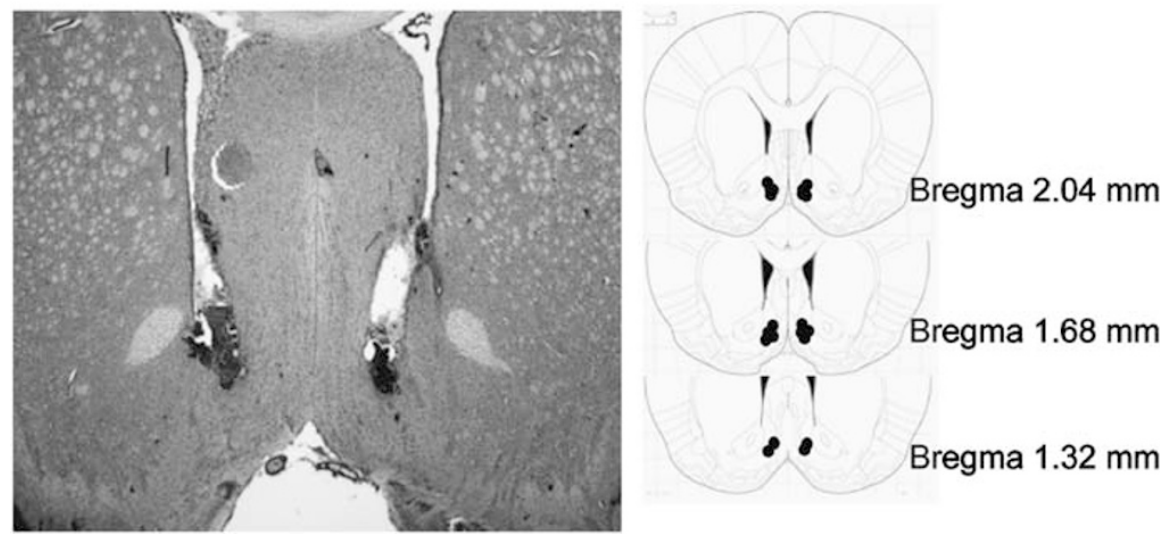

Figure I Effects of intra-NAc shell LY379268 injections on context-induced reinstatement of heroin seeking. (a) Training: mean \pm SEM infusions, and active and inactive lever responses during the 12 days of heroin self-administration training. Rats were trained on an FR-I schedule with a $2.3 \mathrm{~s}$ timeout period; active lever responses reflect infusion + timeout responses. The unit dose of heroin was $0.1 \mathrm{mg} / \mathrm{kg}$ for the first six sessions and $0.05 \mathrm{mg} / \mathrm{kg}$ for the last six sessions ( $n=25$, three groups). (b) Extinction: mean responses on the previously active lever and on the inactive lever during extinction sessions conducted in the absence of heroin and in a context different from the training context $(n=25)$. (c) Test for reinstatement: active lever: mean responses on the active lever after bilateral intra-NAc shell injections of vehicle, 0.3 or $1.0 \mu \mathrm{g}$ of LY379268 in the training or the extinction context. *Different from the vehicle condition, $p<0.05$ ( $n=8-9 / g r o u p)$. (d) Test for reinstatement: inactive lever: mean responses on the inactive lever after intra-NAc shell injections of vehicle or LY379268. (e) A representative picture of NAc shell injector tip and the approximate placements of the injectors' tip of the rats (Paxinos and Watson, 2005)

Condition $\left(\mathrm{F}_{(1,26)}=13.8, p<0.01\right)$, due to a modest increase in responding on this lever in the training context; the effect of LY379268 Dose or LY379268 Dose by Test Context, however, was not significant ( $p$-values $>0.15)$. Post hoc group differences are indicated in Figure $2 c$.
Caudate-putamen. Intracaudate-putamen injections of LY379268 had no effect on lever responding when rats were exposed to the training context after extinction in the different context; LY379268 had no effect on active lever responding in the extinction context or on inactive 

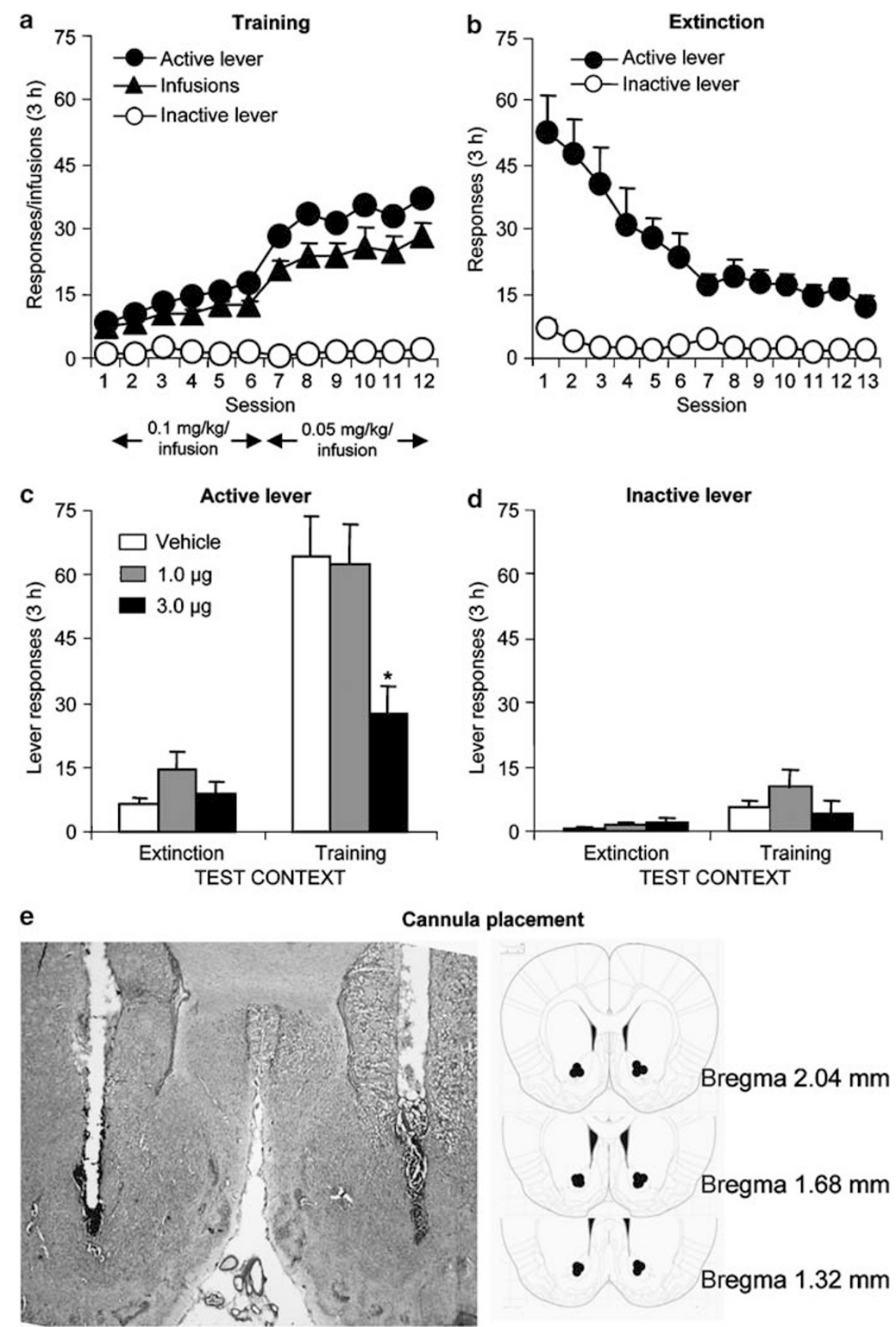

Figure 2 Effects of intra-NAc core LY379268 injections on context-induced reinstatement of heroin seeking. (a) Training: mean \pm SEM infusions, and active and inactive lever responses during the 12 days of heroin self-administration training. Rats were trained on an FR- 1 schedule with a $2.3 \mathrm{~s}$ timeout period; active lever responses reflect infusion + timeout responses. The unit dose of heroin was $0.1 \mathrm{mg} / \mathrm{kg}$ for the first six sessions and $0.05 \mathrm{mg} / \mathrm{kg}$ for the last six sessions ( $n=29$, three groups). (b) Extinction: mean responses on the previously active lever and on the inactive lever during extinction sessions conducted in the absence of heroin and in a context different from the training context $(n=29)$. (c) Test for reinstatement: active lever: mean responses on the active lever after bilateral injections of vehicle, I.0, or $3.0 \mu \mathrm{g}$ of LY379268 in the training or the extinction context. *Different from the vehicle condition, $p<0.05$ ( $n=9-10 /$ group). (d) Test for reinstatement: inactive lever: mean responses on the inactive lever after injections of vehicle or LY379268. (e) A representative picture of NAc core injector tip and the approximate placements of the injectors' tip of the rats (Paxinos and Watson, 2005).

lever responding in the training or the extinction context (Figure $3 \mathrm{c}$ and d). Statistical analysis revealed a significant main effect for active lever responding of Test Context $\left(\mathrm{F}_{(1,12)}=34.5, p<0.01\right)$, but not for the main effect of LY379268 Dose or for the interaction of LY379268 Dose by Test Context ( $p$-values $>0.3)$. The analysis of inactive lever responding revealed a significant effect of Test Condition $\left(\mathrm{F}_{(1,12)}=5.1, p<0.05\right)$, due to a modest increase in responding on this lever in the training context; the effect of LY379268 Dose or LY379268 Dose by Test Context, however, was not significant $(p$-values $>0.1)$. 
a

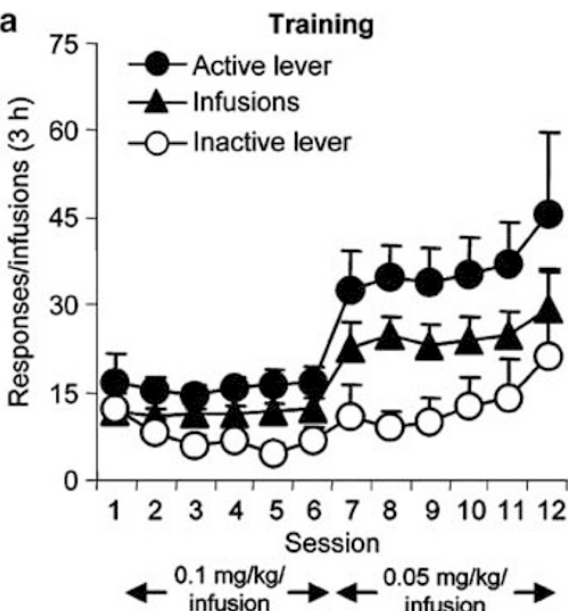

C

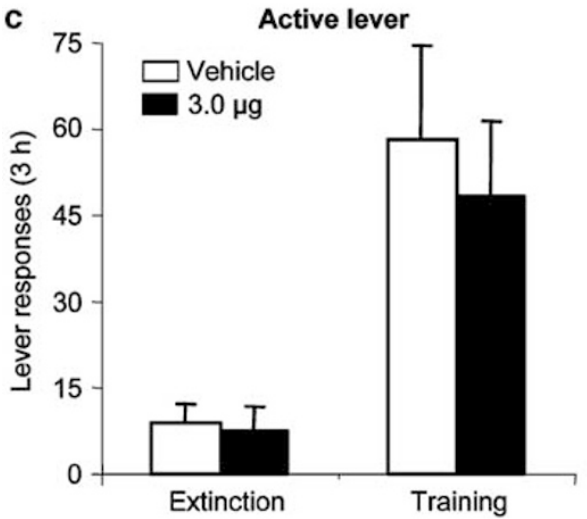

TEST CONTEXT

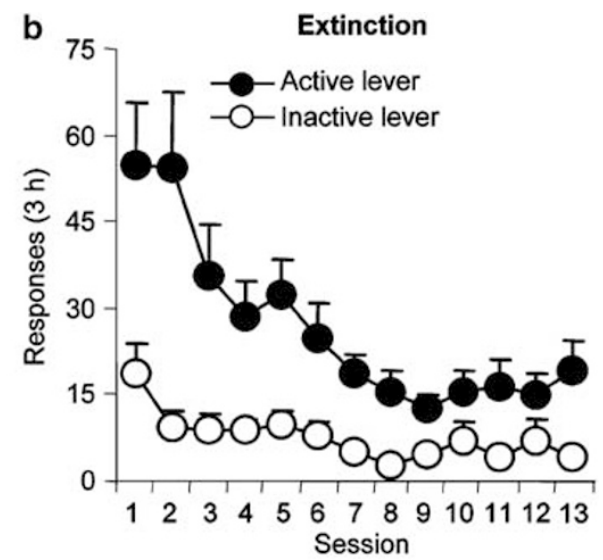

d

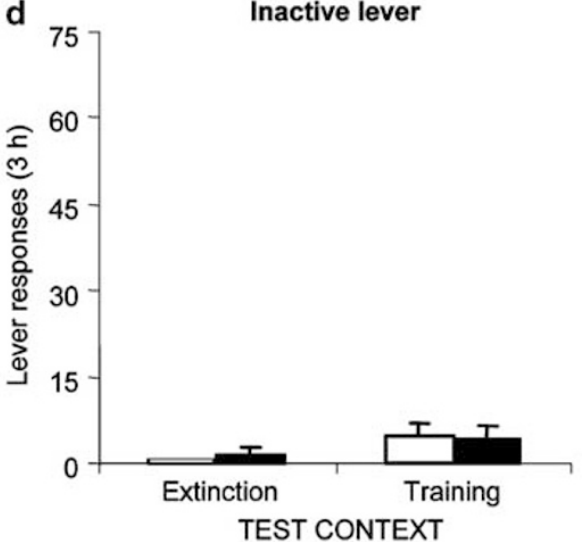

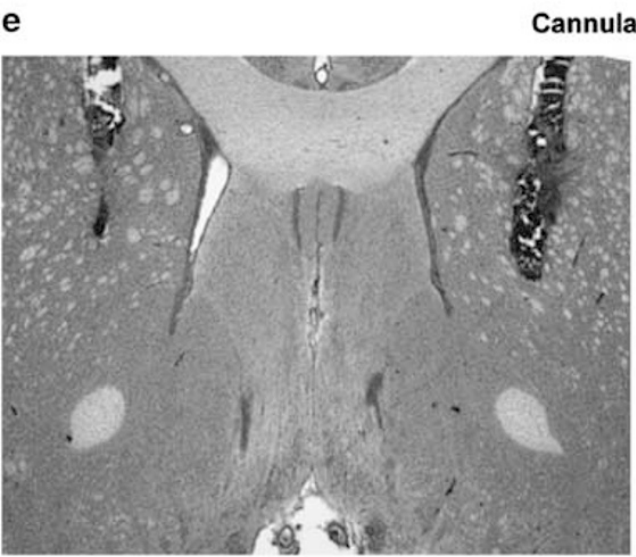

Cannula placement

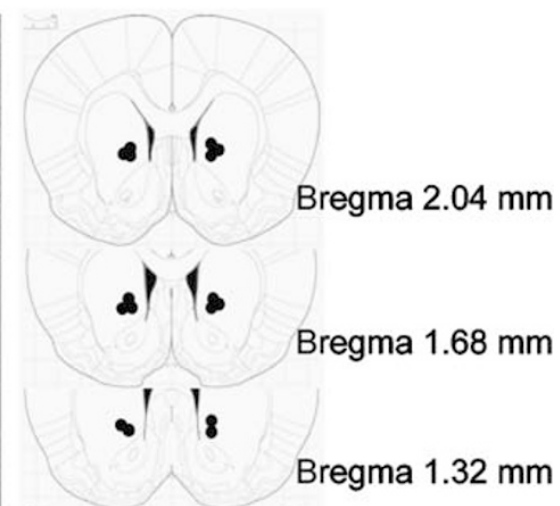

Figure 3 Effects of intracaudate-putamen LY379268 injections on context-induced reinstatement of heroin seeking. (a) Training: mean \pm SEM infusions, and active and inactive lever responses during the 12 days of heroin self-administration training. Rats were trained on an FR-I schedule with a $2.3 \mathrm{~s}$ timeout period; active lever responses reflect infusion + timeout responses. The unit dose of heroin was $0.1 \mathrm{mg} / \mathrm{kg}$ for the first six sessions and $0.05 \mathrm{mg} / \mathrm{kg}$ for the last six sessions ( $n=15$, two groups). (b) Extinction: Mean responses on the previously active lever and on the inactive lever during extinction sessions conducted in the absence of heroin in a context different from the training context $(n=15)$. (c) Test for reinstatement: active lever: mean responses on the active lever after bilateral injections of vehicle or $3.0 \mu \mathrm{g}$ of LY379268 in the training or the extinction context ( $n=7-8 / g r o u p)$. (d) Test for reinstatement: inactive lever: mean responses on the inactive lever after injections of vehicle or LY379268. (e) A representative picture of caudate-putamen injector tip and the approximate placements of the injectors' tip of the rats (Paxinos and Watson, 2005).

\section{Experiment 2: Effect of Intracranial Injections of LY379268 on Lever Responding for Sucrose}

Figure 4 shows the mean \pm SEM number of active and inactive lever responses $(1 \mathrm{~h})$ for the rats that were trained to self-administer oral sucrose after injections of $0,0.3$, and $1.0 \mu \mathrm{g}$ LY379268 into the NAc shell, or $0,1.0$, and $3.0 \mu \mathrm{g}$ into the NAc core. Injections of LY379268 had no effect on lever responding for the oral sucrose ( $p$-values $>0.2$ for LY379268 Dose). 

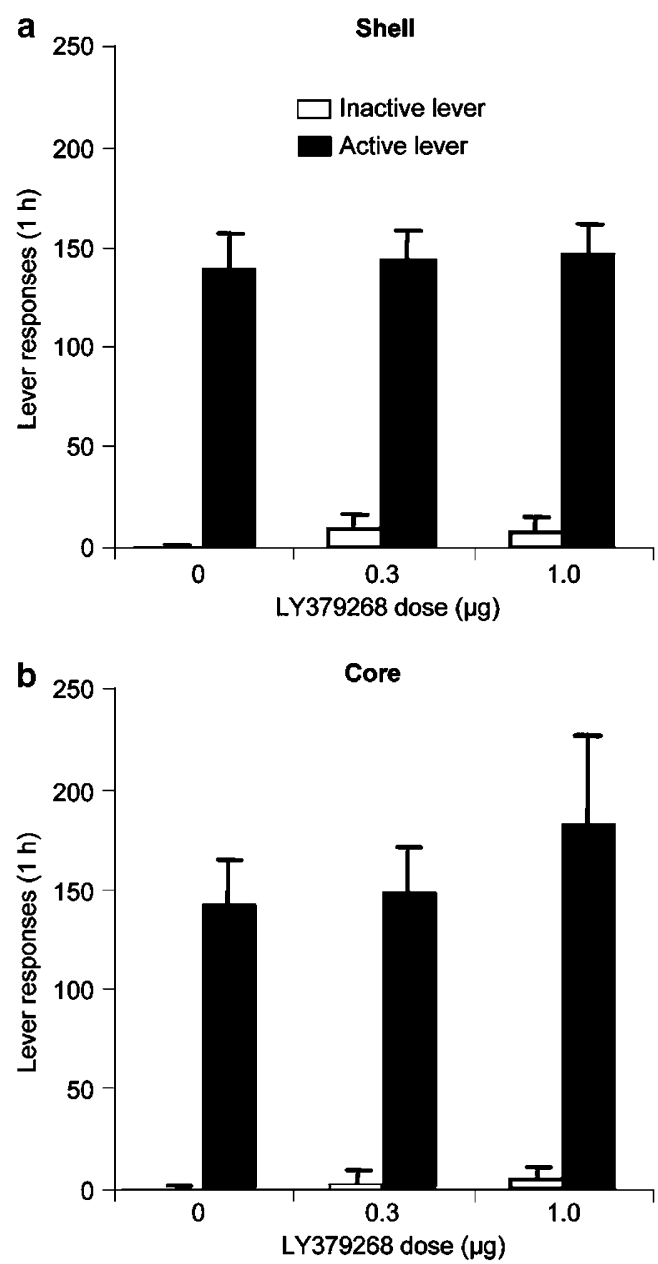

Figure 4 Effect of intra-NAc shell or core injections of LY379268 on sucrose self-administration. Mean \pm SEM responses on the active and the inactive levers after bilateral injections of vehicle or LY379268 into the NAc shell (a) $(0.3$ and I.0 $\mu$ g; $n=5)$ or into the NAc core (b) (I.0 and $3.0 \mu \mathrm{g}$; $n=7)$. No significant effects were observed.

\section{DISCUSSION}

The main finding of this report is that injections of the mGluR $_{2 / 3}$ agonist LY379268 $(0.3$ and $1.0 \mu \mathrm{g})$ into the NAc shell dose-dependently attenuate context-induced reinstatement of heroin seeking. Injections of $1.0 \mu \mathrm{g}$ of LY379268 into the NAc core had no effect on context-induced reinstatement, while injections of a higher dose $(3.0 \mu \mathrm{g})$ into this site attenuate this reinstatement. Injections of LY379268 $(3.0 \mu \mathrm{g}) 1.5 \mathrm{~mm}$ dorsal to the NAc core into the caudate-putamen were ineffective. Importantly, motor deficits cannot account to the effect of NAc injections of LY379268 on context-induced reinstatement; these injections had no effect on higher rates of lever responding for oral sucrose (Figure 4). It is also unlikely that the effect of LY379268 injections into the NAc shell is due to diffusion into the lateral ventricles. The cannulae were implanted at an angle in order to avoid the ventricles and NAc core or caudate-putamen injections of 1.0 or $3.0 \mu \mathrm{g}$, respectively (which were also in close proximity to the ventricles) had no effect. The present results suggest an important role of glutamate transmission in the NAc shell in context-induced reinstatement of heroin seeking and extend our recent finding on the role of VTA glutamate in this reinstatement (Bossert et al, 2004). Our results also tentatively suggest that glutamate transmission in the NAc core has some role in context-induced reinstatement. However, the effective dose in the NAc core was 10 times higher than that in the NAc shell. Thus, the effects observed after NAc core injections may be due to diffusion into the NAc shell. Finally, our results suggest that glutamate transmission in the caudateputamen is not involved in context-induced reinstatement. However, this conclusion is tentative because our injections targeted the ventral part of the caudate-putamen; it was recently reported that blockade of AMPA receptors in the dorsal caudate-putamen attenuates discrete cue-controlled cocaine seeking (Vanderschuren et al, 2005), but see Kantak et al (2002) for different results.

\section{Neuronal Mechanisms Underlying the Effect of LY379268 NAc Injections on Reinstatement}

LY379268 is an agonist of the $\mathrm{mGluR}_{2}$ and $\mathrm{mGluR}_{3}$ receptors and thus both receptors may be involved in its effects on context-induced reinstatement. $\mathrm{mGluR}_{3}$ is expressed on both pre- and postsynaptic sites in the NAc and the caudate-putamen (Ohishi et al, 1993b; Tamaru et al, 2001). mGluR $_{2}$ in these brain areas is selectively expressed on presynaptic sites (Testa et al, 1998; Richards et al, 2005). Results from anatomical studies do not indicate differential distribution of $\mathrm{mGluR}_{2}$ or $\mathrm{mGluR}_{3}$ receptors in the NAc core, shell, and striatum (Petralia et al, 1996; Ohishi et al, 1998; Richards et al, 2005). In the NAc, agonist activation of mGluR $2 / 3$ receptors decreases excitatory synaptic transmission via presynaptic mechanisms (Manzoni et al, 1997) and decreases glutamate levels, as measured by microdialysis (Xi et al, 2002). Based on the above findings, a plausible interpretation of the present data is that exposure to the heroin context increases excitatory glutamate transmission in the NAc shell and this effect is reversed by local injections of LY379268. Within this framework, it is likely that the postsynaptic effects of NAc glutamate on contextinduced reinstatement involve AMPA receptors because previous research has shown that blockade (rather than activation) of NMDA receptors in the NAc shell supports self-administration and induces reinstatement of cocaine seeking (Carlezon and Wise, 1996; Park et al, 2002).

The effect of intra-NAc shell injections of LY379268 on context-induced reinstatement may also involve its effect on context-induced NAc dopamine release. Systemic injections of LY379268 attenuate amphetamine-induced dopamine release (Kim et al, 2005) and agonist activation of NAc $\mathrm{mGluR}_{2 / 3}$ decreases dopamine release (microdialysis probes were aimed at both the NAc core and shell). In addition, and potentially highly relevant to our results, local infusions of LY379268 reduce dopamine levels in the NAc shell, but not in the core (Greenslade and Mitchell, 2004). Other support for the notion that activation of NAc shell dopamine contributes to the effect of the drug context on reinstatement is the finding that exposure to cocaine-predictive discriminative stimuli increases NAc dopamine release (Weiss et al, 2000). Furthermore, dopamine receptor antagonists attenuate both context- and discriminative cue-induced reinstatement of cocaine seeking (Ciccocioppo 
et al, 2001; Weiss et al, 2001; Crombag et al, 2002). We also found that low doses of the D1-like receptor antagonist SCH $23390(2.5$ and $5.0 \mu \mathrm{g} / \mathrm{kg}$, s.c. $)$ attenuate context-induced reinstatement of heroin seeking (JM Bossert, unpublished data). Finally, our findings that intra-VTA injections of LY379268 attenuate context-induced reinstatement (Bossert et al, 2004) are in agreement with the notion that dopamine in the NAc shell is involved in this effect. In this regard, a potential scenario is that exposure to the drug-associated context activates glutamate neurons projecting to the VTA that in turn activate VTA dopamine cell body neurons, resulting in increases in dopamine release in the NAc (Westerink et al, 1996; Giorgetti et al, 2001).

Taken together, we speculate that both glutamate and dopamine are likely involved in the effect of intra-NAc shell injections of LY379268 on context-induced reinstatement. A major glutamatergic projection to the medial NAc shell (our injection site) originates from the ventral subiculum (Groenewegen et al, 1987, 1999a), a brain area critically involved in the effect of contextual cues on behavior (Bast et al, 2001; Rudy and Matus-Amat, 2005). In addition, electrical stimulation of the ventral subiculum induces reinstatement of psychostimulant seeking (Vorel et al, 2001; Taepavarapruk and Phillips, 2003). We therefore speculate that context-induced activation of both glutamate projections from the ventral subiculum and dopamine projections from the VTA in the medial NAc shell is necessary for context-induced reinstatement of heroin seeking.

\section{Psychological Mechanisms Underlying the Effect of LY379268 NAc Injections on Reinstatement}

The attenuation of context-induced reinstatement of heroin seeking by intra-NAc LY379268 injections may be due to the effect of these injections on several psychological processes. Contexts may reinstate drug and nondrug reward seeking because of their occasion setter properties (Bouton, 2002; Crombag and Shaham, 2002). Occasion setter cues are different from traditional conditioned stimuli in that they do not elicit behavior, but rather modulate the ability of other conditioned stimuli to provoke learned responses (Bouton and Swartzentruber, 1991; Holland, 1992). In this regard, Bouton (1993) suggested that the context functions as a retrieval cue when the meaning of discrete conditioned stimuli is ambiguous after they have been paired with both reinforcement (training) and non-reinforcement (extinction). We suspect, however, that it is relatively unlikely that intra-NAc infusions of LY379268 selectively interfered with memory retrieval. In a review of the literature on the role of the NAc in learning and memory, Setlow (1997) concluded that '...the NAc is involved in learning and/or consolidation, but not in retrieval, suggesting that the NAc is a permanent site of memory storage' (p 517). For example, Sutherland and Rodriguez (1989) found that prior to training, lesions of the NAc impaired learning in a spatial version of the Morris water-maze task; however, when lesions were performed post-training, they had no effect on task performance, see also Ploeger et al (1994), but see Seamans and Phillips (1994) for different results in a study using a radial arm-maze task. In addition, Haralambous and Westbrook (1999) reported that NAc inactivation disrupts the acquisition, but not the expression, of contextual fear conditioning. Finally, Miller and Marshall (2005) recently reported that ERK (an intracellular signaling pathway that is activated in mesolimbic areas by exposure to drug and drug cues; Valjent et al, 2004; Lu et al, 2005) in the NAc core, but not shell, is important for the retrieval and reconsolidation of the memory of cocaine-associated cues.

Alternatively, the heroin context may induce drug seeking because it previously acquired motivational properties via its direct association with heroin reward during training (Stewart et al, 1984). Within this framework, the attenuation of glutamate (and potentially dopamine) transmission by intra-NAc LY379268 injections is hypothesized to decrease an incentive motivational state, induced by exposure to the contextual cues, which leads to reinstatement of heroin seeking. The findings that blockade of ionotropic excitatory glutamate receptors in the NAc attenuates the expression of conditioned place preference for morphine (Layer et al, 1993) is in agreement with this interpretation. The conditioned place preference procedure is commonly used to assess the incentive motivational effects of opiates and other drugs (Stewart et al, 1984; Phillips and Fibiger, 1987; Bardo and Bevins, 2000). Taken together, we propose that the effect NAc injections of LY379268 on context-induced reinstatement is due to decreases in the motivational significance of the heroin context rather than interference with memory retrieval.

\section{Role of the NAc Core and Shell in Drug Seeking}

The core and shell of the NAc are heterogeneous structures with distinct immunohistochemical characteristics, and afferent input and efferent projections (Voorn et al, 1989; Heimer et al, 1991; Zahm and Brog, 1992). These neuroanatomical findings inspired many investigations on the different roles of the NAc core and shell in motivated behavior (Cardinal et al, 2002; Kelley, 2004), and in the conditioned and unconditioned rewarding effects of drugs (Everitt and Wolf, 2002; Di Chiara et al, 2004; Ikemoto and Wise, 2004). In the context of drug self-administration and reinstatement studies, it is difficult to integrate our current findings on the role of NAc shell glutamate in contextinduced reinstatement of heroin seeking with previous studies on the differential role of the core and shell in drug seeking because most of these previous studies were performed with cocaine-trained rats and assessed drug seeking induced by exposure to discrete drug cues or priming drug injections. Nevertheless, it appears that our findings, which suggest a critical role of NAc shell glutamate in context-induced reinstatement of heroin seeking, diverge from two dominant current hypotheses on the neuronal circuitry underlying cue-controlled drug seeking (Everitt and Wolf, 2002; Di Ciano and Everitt, 2005) and drug relapse (Kalivas and Volkow, 2005) that emphasize the critical role of NAc core glutamate.

In studies on the neuronal circuits underlying cueinduced cocaine seeking it was found that blockade of AMPA receptors in the NAc core, but not the shell, attenuates lever responding maintained by discrete cues in a second-order schedule procedure (Di Ciano and Everitt, 2001); in this procedure, the conditioned reinforcing properties of the contingent discrete cues control drug seeking (Goldberg, 1976; Everitt and Robbins, 2000; 
Schindler et al, 2002). The finding of Di Ciano and Everitt are in agreement with those demonstrating that permanent NAc core lesions had a more pronounced effect than NAc shell lesions on responding reinforced by heroin or cocaine cues in this procedure (Hutcheson et al, 2001; Ito et al, 2004). Fuchs et al (2004) reported that reversible inactivation (muscimol + baclofen injections) of the NAc core, but not the shell, attenuates discrete cue-induced reinstatement of cocaine seeking; the discrete cues were presented contingently during testing. Also potentially relevant here is the finding that reversible inactivation of the dorsomedial prefrontal cortex (tetrodotoxin injections), but not the ventromedial prefrontal cortex, attenuates context-induced reinstatement of cocaine seeking, as measured in a procedure similar to the one used in our study (Fuchs et al, 2005). Glutamatergic projections from the dorsomedial and ventromedial prefrontal cortex preferentially innervate the NAc core and shell, respectively (Voorn et al, 2004).

Results from studies on the brain sites underlying cocaine priming-induced reinstatement of drug seeking point to a critical role of activation of AMPA receptors in the NAc core by glutamate projections from the dorsomedial prefrontal cortex (Cornish and Kalivas, 2000; McFarland et al, 2003). Based on these and other findings, Kalivas suggested that activation of this glutamatergic projection serves as a final common pathway for relapse to drugs (Kalivas, 2004).

Results from one study, however, are in agreement with the present results and support the idea that the NAc shell plays an important role in drug seeking induced by background environmental cues. Using a discriminative cue reinstatement procedure similar to that developed by Weiss et al (2000), Ghitza et al (2003) found that neurons in the NAc shell, but not the core, change their firing activity when rats were re-exposed to discriminative stimuli that previously predicted cocaine availability. These findings are relevant to the present results because while our contextinduced reinstatement method is procedurally different from the discriminative cue-induced reinstatement method of Weiss and colleagues, it is likely that similar neuronal substrates underlie cue-induced drug seeking, as measured in these methods: in both cases background environmental cues that become predictors of drug availability during training induce drug seeking following extinction of the operant self-administration responding in the absence of these cues. Therefore, our data and those from previous studies suggest that glutamate in the NAc core plays an important role in reinstatement induced by discrete cues and drug priming, while glutamate in the NAc shell plays an important role in reinstatement induced by discriminative and contextual cues.

\section{Concluding Remarks}

We found that intra-NAc shell injections of LY379268 dosedependently attenuate context-induced reinstatement of heroin seeking, suggesting an important role of glutamate (and possibly dopamine) transmission in the NAc shell in context-induced reinstatement of heroin seeking. These findings diverge from those indicating a critical role of NAC core glutamate in drug seeking induced by contingent exposure to discrete drug cues or drug priming injections
(Cornish and Kalivas, 2000; Di Ciano and Everitt, 2001). These different findings suggest that glutamate transmission in the NAc core and shell plays dissociable roles in drug seeking induced by exposure to contextual (and possibly discriminative) $v s$ exposure to contingent discrete drug cues or acute re-exposure to the self-administered drug. Finally, the present findings on the effect of intra-NAc LY379268 injections in a rat relapse model extend those from our previous study on the effect of systemic and intraVTA injections of the drug on context-induced reinstatement of heroin seeking (Bossert et al, 2004). It was also reported that systemic injections of LY379268 attenuate (1) discrete cue-induced reinstatement of heroin seeking (Bossert et al, 2005), (2) discriminative cue-induced reinstatement of cocaine seeking (Baptista et al, 2004), (3) cocaine priming-induced reinstatement (Peters et al, 2004), (4) enhanced amphetamine-taking behavior by prior sensitizing exposure to the drug (Kim et al, 2005), and (5) other behavioral effects of abused drugs (Kenny and Markou, 2004). Together, these results from preclinical studies suggest that pharmacological manipulations that target group II metabotropic glutamate receptors should be considered in the treatment of drug addiction.

\section{ACKNOWLEDGEMENTS}

The work was supported by the Intramural Research Program of the National Institute on Drug Abuse. We thank Robert Busch and Gabriela Poles for help in conducting this study, Drs Udi Ghitza and Zheng-Xiong $\mathrm{Xi}$ for helpful comments, and Dr David McKinzie from Eli-Lilly for providing LY379268.

\section{REFERENCES}

Anwyl R (1999). Metabotropic glutamate receptors: electrophysiological properties and role in plasticity. Brain Res Rev 29: 83-120.

Baptista MA, Martin-Fardon R, Weiss F (2004). Preferential effects of the metabotropic glutamate $2 / 3$ receptor agonist LY379268 on conditioned reinstatement versus primary reinforcement: comparison between cocaine and a potent conventional reinforcer. J Neurosci 24: 4723-4727.

Bardo MT, Bevins RA (2000). Conditioned place preference: what does it add to our preclinical understanding of drug reward? Psychopharmacology 153: 31-43.

Bast T, Zhang WN, Feldon J (2001). The ventral hippocampus and fear conditioning in rats. Different anterograde amnesias of fear after tetrodotoxin inactivation and infusion of the GABA(A) agonist muscimol. Exp Brain Res 139: 39-52.

Bossert JM, Busch RF, Gray SM (2005). The novel mGluR2/3 agonist LY379268 attenuates cue-induced reinstatement of heroin seeking. Neuroreport 16: 1013-1016.

Bossert JM, Liu SY, Lu L, Shaham Y (2004). A role of ventral tegmental area glutamate in contextual cue-induced relapse to heroin seeking. J Neurosci 24: 10726-10730.

Bouton ME (1993). Context, time, and memory retrieval in the interference paradigms of Pavlovian learning. Psychol Bull 114: 80-99.

Bouton ME (2002). Context, ambiguity, and unlearning: sources of relapse after behavioral extinction. Biol Psychiatr 52: 976-986.

Bouton ME, Bolles RC (1979). Contextual control of the extinction of conditioned fear. Learn Motiv 10: 445-466. 
Bouton ME, Swartzentruber D (1991). Sources of relapse after extinction in Pavlovian and instrumental learning. Clin Psychol Rev 11: 123-140.

Brog JS, Salyapongse A, Deutch AY, Zahm DS (1993). The patterns of afferent innervation of the core and shell in the 'accumbens' part of the rat ventral striatum: immunohistochemical detection of retrogradely transported fluoro-gold. J Comp Neurol 338: 255-278.

Cardinal RN, Parkinson JA, Hall J, Everitt BJ (2002). Emotion and motivation: the role of the amygdala, ventral striatum, and prefrontal cortex. Neurosci Biobehav Rev 26: 321-352.

Carlezon Jr WA, Boundy VA, Haile CN, Lane SB, Kalb RG, Neve RL et al (1997). Sensitization to morphine induced by viralmediated gene transfer. Science 277: 812-814.

Carlezon WA, Wise RA (1996). Rewarding actions of phencyclidine and related drugs in nucleus accumbens shell and frontal cortex. J Neurosci 16: 3112-3122.

Ciccocioppo R, Sanna PP, Weiss F (2001). Cocaine-predictive stimulus induces drug-seeking behavior and neural activation in limbic brain regions after multiple months of abstinence: reversal by $\mathrm{D}(1)$ antagonists. Proc Natl Acad Sci USA 98: 1976-1981.

Cornish JL, Kalivas PW (2000). Glutamate transmission in the nucleus accumbens mediates relapse in cocaine addiction. J Neurosci 20: RC89.

Crombag H, Grimm JW, Shaham Y (2002). Effect of dopamine receptor antagonists on renewal of cocaine seeking by reexposure to drug-associated contextual cues. Neuropsychopharmacology 27: 1007-1016.

Crombag HS, Shaham Y (2002). Renewal of drug seeking by contextual cues after prolonged extinction in rats. Behav Neurosci 116: 169-173.

Davis WM, Smith SG (1976). Role of conditioned reinforcers in the initiation, maintenance and extinction of drug-seeking behavior. Pavlovian J Biol Sci 11: 222-236.

Di Chiara G, Bassareo V, Fenu S, De Luca MA, Spina L, Cadoni C et al (2004). Dopamine and drug addiction: the nucleus accumbens shell connection. Neuropharmacology 47(Suppl 1): 227-241.

Di Ciano P, Everitt BJ (2001). Dissociable effects of antagonism of NMDA and AMPA/KA receptors in the nucleus accumbens core and shell on cocaine-seeking behavior. Neuropsychopharmacology 25: 341-360.

Di Ciano P, Everitt BJ (2005). Neuropharmacology of compulsive drug seeking: Insights from studies with second-order schedules of drug reinforcement. Eur J Pharmacol (in press).

Everitt BJ, Dickinson A, Robbins TW (2001). The neuropsychological basis of addictive behaviour. Brain Res Rev 36: 129-138.

Everitt BJ, Robbins TW (2000). Second-order schedules of drug reinforcement in rats and monkeys: measurement of reinforcing efficacy and drug-seeking behaviour. Psychopharmacology 153: $17-30$

Everitt BJ, Wolf ME (2002). Psychomotor stimulant addiction: a neural systems perspective. J Neurosci 22: 3312-3320.

Fuchs RA, Evans KA, Ledford CC, Parker MP, Case JM, Mehta RH et al (2005). The role of the dorsomedial prefrontal cortex, basolateral amygdala, and dorsal hippocampus in contextual reinstatement of cocaine seeking in rats. Neuropsychopharmacology 30: 296-309.

Fuchs RA, Evans KA, Parker MC, See RE (2004). Differential involvement of the core and shell subregions of the nucleus accumbens in conditioned cue-induced reinstatement of cocaine seeking in rats. Psychopharmacology (Berlin) 176: 459-465.

Fuchs RA, See RE (2002). Basolateral amygdala inactivation abolishes conditioned stimulus- and heroin-induced reinstatement of extinguished heroin-seeking behavior in rats. Psychopharmacology 160: 425-433.
Ghitza UE, Fabbricatore AT, Prokopenko V, Pawlak AP, West MO (2003). Persistent cue-evoked activity of accumbens neurons after prolonged abstinence from self-administered cocaine. J Neurosci 23: 7239-7245.

Giorgetti M, Hotsenpiller G, Ward P, Teppen T, Wolf ME (2001). Amphetamine-induced plasticity of AMPA receptors in the ventral tegmental area: effects on extracellular levels of dopamine and glutamate in freely moving rats. J Neurosci 21: 6362-6369.

Goldberg SR (1976). Stimuli associated with drug injections as events that control behavior. Pharmacol Rev 27: 325-340.

Gracy KN, Dankiewicz LA, Weiss F, Koob GF (2000). Heroinspecific stimuli reinstate operant heroin-seeking behavior in rats after prolonged extinction. Pharmacol Biochem Behav 65: 489-494.

Greenslade RG, Mitchell SN (2004). Selective action of (-)-2oxa-4-aminobicyclo[3.1.0] hexane-4, 6-dicarboxylate (LY379268), a group II metabotropic glutamate receptor agonist, on basal and phencyclidine-induced dopamine release in the nucleus accumbens shell. Neuropharmacology 47: 1-8.

Groenewegen HJ, Mulder AB, Beijer AVJ, Wright CI, Lopez DA, Silva FH et al (1999a). Hippocampal and amygdaloid interactions in the nucleus accumbens. Psychobiology 27: 149-164.

Groenewegen HJ, Vermeulen-Van der Zee E, te Kortschot A, Witter MP (1987). Organization of the projections from the subiculum to the ventral striatum in the rat. A study using anterograde transport of Phaseolus vulgaris leucoagglutinin. Neuroscience 23: 103-120.

Groenewegen HJ, Wright CI, Beijer AV, Voorn P (1999b). Convergence and segregation of ventral striatal inputs and outputs. Ann NY Acad Sci 877: 49-63.

Gunther LM, Denniston JC, Miller RR (1998). Conducting exposure treatment in multiple contexts can prevent relapse. Behav Res Ther 36: 75-91.

Haralambous T, Westbrook RF (1999). An infusion of bupivacaine into the nucleus accumbens disrupts the acquisition but not the expression of contextual fear conditioning. Behav Neurosci 113: 925-940.

Harris GC, Wimmer M, Byrne R, Aston-Jones G (2004). Glutamateassociated plasticity in the ventral tegmental area is necessary for conditioning environmental stimuli with morphine. Neuroscience 129: 841-847.

Heimer L, Alheid GF, de Olmos JS, Groenewegen HJ, Haber SN, Harlan RE et al (1997). The accumbens: beyond the core-shell dichotomy. J Neuropsychiatr Clin Neurosci 9: 354-381.

Heimer L, Zahm DS, Churchill L, Kalivas PW, Wohltmann C (1991). Specificity in the projection patterns of accumbal core and shell in the rat. Neuroscience 41: 89-125.

Highfield D, Clements A, Shalev U, McDonald RJ, Featherstone R, Stewart J et al (2000). Involvement of the medial septum in stress-induced relapse to heroin seeking in rats. Eur J Neurosci 12: $1705-1713$.

Holland PC (1992). Occasion setting in Pavlovian conditioning. In: Medlin DL (ed). The Psychology and Learning and Motivation. Academic Press: San Diego, CA. pp 69-125.

Hotsenpiller G, Giorgetti M, Wolf ME (2001). Alterations in behaviour and glutamate transmission following presentation of stimuli previously associated with cocaine exposure. Eur J Neurosci 14: 1843-1855.

Hutcheson DM, Parkinson JA, Robbins TW, Everitt BJ (2001). The effects of nucleus accumbens core and shell lesions on intravenous heroin self-administration and the acquisition of drug-seeking behaviour under a second-order schedule of heroin reinforcement. Psychopharmacology 153: 464-472.

Hyytia P, Backstrom P (2005). Glutamatergic control of cueinduced reinstatement of alcohol- and cocaine-seeking behaviour. Behav Pharmacol 16(Suppl 1): S3. 
Ikemoto S, Wise RA (2004). Mapping of chemical trigger zones for reward. Neuropharmacology 47(Suppl 1): 190-201.

Ito R, Dalley JW, Robbins TW, Everitt BJ (2002). Dopamine release in the dorsal striatum during cocaine-seeking behavior under the control of a drug-associated cue. J Neurosci 22: 6247-6253.

Ito R, Robbins TW, Everitt BJ (2004). Differential control over cocaine-seeking behavior by nucleus accumbens core and shell. Nat Neurosci 7: 389-397.

Kaddis FG, Uretsky NJ, Wallace LJ (1995). DNQX in the nucleus accumbens inhibits cocaine-induced conditioned place preference. Brain Res 697: 76-82.

Kalivas PW (2004). Glutamate systems in cocaine addiction. Curr Opin Pharmacol 4: 23-29.

Kalivas PW, Volkow ND (2005). The neural basis of addiction: a pathology of motivation and choice. Am J Psychiatr 162: 1403-1413.

Kantak KM, Black Y, Valencia E, Green-Jordan K, Eichenbaum HB (2002). Dissociable effects of lidocaine inactivation of the rostral and caudal basolateral amygdala on the maintenance and reinstatement of cocaine-seeking behavior in rats. J Neurosci 22: 1126-1136.

Kelley AE (2004). Ventral striatal control of appetitive motivation: role in ingestive behavior and reward-related learning. Neurosci Biobehav Rev 27: 765-776.

Kenny PJ, Markou A (2004). The ups and downs of addiction: role of metabotropic glutamate receptors. Trends Pharmacol Sci 25: 265-272.

Kim JH, Austin JD, Tanabe L, Creekmore E, Vezina P (2005). Activation of group II mGlu receptors blocks the enhanced drug taking induced by previous exposure to amphetamine. Eur $J$ Neurosci 21: 295-300.

Kim JH, Vezina P (2002). The mGlu2/3 receptor agonist LY379268 blocks the expression of locomotor sensitization by amphetamine. Pharmacol Biochem Behav 73: 333-337.

Layer RT, Uretsky NJ, Wallace LJ (1993). Effects of the AMPA/ kainate receptor antagonist DNQX in the nucleus accumbens on drug-induced conditioned place preference. Brain Res 617: 267-273.

Lu L, Hope BT, Dempsey J, Liu SY, Bossert JM, Shaham Y (2005). Central amygdala ERK signaling pathway is critical to incubation of cocaine craving. Nat Neurosci 8: 212-219.

Manzoni O, Michel JM, Bockaert J (1997). Metabotropic glutamate receptors in the rat nucleus accumbens. Eur J Neurosci 9: 1514-1523.

McFarland K, Ettenberg A (1997). Reinstatement of drug-seeking behavior produced by heroin-predictive environmental stimuli. Psychopharmacology 131: 86-92.

McFarland K, Lapish CC, Kalivas PW (2003). Prefrontal glutamate release into the core of the nucleus accumbens mediates cocaineinduced reinstatement of drug-seeking behavior. J Neurosci 23: 3531-3537.

Miller CA, Marshall JF (2005). Molecular substrates for retrieval and reconsolidation of cocaine-associated contextual memory. Neuron 47: 873-884.

O’Brien CP, Childress AR, Mclellan TA, Ehrman R (1992). Classical conditioning in drug dependent humans. Ann NY Acad Sci 654: 400-415.

Ohishi H, Neki A, Mizuno N (1998). Distribution of a metabotropic glutamate receptor, mGluR2, in the central nervous system of the rat and mouse: an immunohistochemical study with a monoclonal antibody. Neurosci Res 30: 65-82.

Ohishi H, Shigemoto R, Nakanishi S, Mizuno N (1993a). Distribution of the messenger RNA for a metabotropic glutamate receptor, mGluR2, in the central nervous system of the rat. Neuroscience 53: 1009-1018.

Ohishi H, Shigemoto R, Nakanishi S, Mizuno N (1993b). Distribution of the mRNA for a metabotropic glutamate receptor
(mGluR3) in the rat brain: an in situ hybridization study. J Comp Neurol 335: 252-266.

Park WK, Bari AA, Jey AR, Anderson SM, Spealman RD, Rowlett JK et al (2002). Cocaine administered into the medial preforntal cortex reinstates cocaine-seeking behavior by increasing AMPA receptor-mediated glutamate transmission in the nucleus accumbens. J Neurosci 22: 2916-2925.

Paxinos G, Watson C (2005). The Rat Brain in Stereotaxic Coordinates. Elsevier Academic Press: Amsterdam.

Peters JL, McFarland K, Kalivas PW (2004). Group II metabotropic glutamate receptors mediate cocaine-seeking behavior in an animal model of relapse. Soc Neurosci Abstr (No 4632).

Petralia RS, Wang YX, Niedzielski AS, Wenthold RJ (1996). The metabotropic glutamate receptors, mGluR2 and mGluR3, show unique postsynaptic, presynaptic and glial localizations. Neuroscience 71: 949-976.

Phillips AG, Fibiger HC (1987). Anatomical and neurochemical substrates of drug reward determined by the conditioned place preference technique. In: Bozarth MA (ed). Methods of Assessing the Reinforcing Properties of Abused Drugs. Springer-Verlag: New York. pp 275-290.

Ploeger GE, Spruijt BM, Cools AR (1994). Spatial localization in the Morris water maze in rats: acquisition is affected by intraaccumbens injections of the dopaminergic antagonist haloperidol. Behav Neurosci 108: 927-934.

Richards G, Messer J, Malherbe P, Pink R, Brockhaus M, Stadler H et al (2005). Distribution and abundance of metabotropic glutamate receptor subtype 2 in rat brain revealed by [ $3 \mathrm{H}$ ]LY354740 binding in vitro and quantitative radioautography: correlation with the sites of synthesis, expression, and agonist stimulation of [35S]GTPgammas binding. J Comp Neurol 487: $15-27$

Rudy JW, Matus-Amat P (2005). The ventral hippocampus supports a memory representation of context and contextual fear conditioning: implications for a unitary function of the hippocampus. Behav Neurosci 119: 154-163.

Schindler CW, Panlilio LV, Goldberg SR (2002). Second-order schedules of drug self-administration in animals. Psychopharmacology 163: 327-344.

Schoepp DD (2001). Unveiling the functions of presynaptic metabotropic glutamate receptors in the central nervous system. J Pharmacol Exp Ther 299: 12-20.

Schuster CR, Woods JH (1968). The conditioned reinforcing effects of stimuli associated with morphine reinforcement. Int J Addict 3: $223-230$.

Seamans JK, Phillips AG (1994). Selective memory impairments produced by transient lidocaine-induced lesions of the nucleus accumbens in rats. Behav Neurosci 108: 456-468.

Sellings LH, Clarke PB (2003). Segregation of amphetamine reward and locomotor stimulation between nucleus accumbens medial shell and core. J Neurosci 23: 6295-6303.

Setlow B (1997). The nucleus accumbens and learning and memory. J Neurosci Res 49: 515-521.

Shaham Y, Erb S, Stewart J (2000a). Stress-induced relapse to heroin and cocaine seeking in rats: a review. Brain Res Brain Res Rev 33: 13-33.

Shaham Y, Highfield D, Delfs JM, Leung S, Stewart J (2000b). Clonidine blocks stress-induced reinstatement of heroin seeking in rats: an effect independent of the locus coeruleus noradrenergic neurons. Eur J Neurosci 12: 292-302.

Shaham Y, Shalev U, Lu L, De Wit H, Stewart J (2003). The reinstatement model of drug relapse: history, methodology and major findings. Psychopharmacology 168: 3-20.

Shalev U, Grimm JW, Shaham Y (2002). Neurobiology of relapse to heroin and cocaine seeking: a review. Pharmacol Rev 54: 1-42.

Stewart J, de Wit H, Eikelboom R (1984). Role of unconditioned and conditioned drug effects in the self-administration of opiates and stimulants. Psychol Rev 91: 251-268. 
Sun W, Akins CK, Mattingly AE, Rebec GV (2005). Ionotropic glutamate receptors in the ventral tegmental area regulate cocaine-seeking behavior in rats. Neuropsychopharmacology 30: 2073-2081.

Sutherland RJ, Rodriguez AJ (1989). The role of the fornix/fimbria and some related subcortical structures in place learning and memory. Behav Brain Res 32: 265-277.

Suto N, Tanabe LM, Austin JD, Creekmore E, Pham CT, Vezina P (2004). Previous exposure to psychostimulants enhances the reinstatement of cocaine seeking by nucleus accumbens AMPA. Neuropsychopharmacology 29: 2149-2159.

Taepavarapruk P, Phillips AG (2003). Neurochemical correlates of relapse to d-amphetamine self-administration by rats induced by stimulation of the ventral subiculum. Psychopharmacology (Berlin) 168: 99-108.

Tamaru Y, Nomura S, Mizuno N, Shigemoto R (2001). Distribution of metabotropic glutamate receptor mGluR3 in the mouse CNS: differential location relative to pre- and postsynaptic sites. Neuroscience 106: 481-503.

Testa CM, Friberg IK, Weiss SW, Standaert DG (1998). Immunohistochemical localization of metabotropic glutamate receptors mGluR1a and mGluR2/3 in the rat basal ganglia. J Comp Neurol 390: 5-19.

Valjent E, Pages C, Herve D, Girault JA, Caboche J (2004). Addictive and non-addictive drugs induce distinct and specific patterns of ERK activation in mouse brain. Eur J Neurosci 19: 1826-1836.

Vanderschuren LJ, Di Ciano P, Everitt BJ (2005). Involvement of the dorsal striatum in cue-controlled cocaine seeking. J Neurosci 25: 8665-8870.

Voorn P, Gerfen CR, Groenewegen HJ (1989). Compartmental organization of the ventral striatum of the rat: immunohistochemical distribution of enkephalin, substance $\mathrm{P}$, dopamine, and calcium-binding protein. J Comp Neurol 289: 189-201.

Voorn P, Vanderschuren LJ, Groenewegen HJ, Robbins TW, Pennartz CM (2004). Putting a spin on the dorsal-ventral divide of the striatum. Trends Neurosci 27: 468-474.

Vorel SR, Liu X, Hayes RJ, Spector JA, Gardner EL (2001). Relapse to cocaine-seeking after hippocampal theta burst stimulation. Science 292: 1175-1178.
Wang B, Shaham Y, Zitzman D, Azari S, Wise RA, You ZB (2005). Cocaine experience establishes control of midbrain glutamate and dopamine by cortictotropin-releasing factor: a role in stress-induced relapse to drug seeking. J Neurosci 25: 5389-5396.

Weiss F, Maldonado-Vlaar CS, Parsons LH, Kerr TM, Smit DL, Ben-Shahar O (2000). Control of cocaine-seeking behavior by drug-associated stimuli in rats: effects on recovery of extinguished operant-responding and extracellular dopamine levels in amygdala and nucleus accumbens. Proc Natl Acad Sci USA 97: 4321-4326.

Weiss F, Martin-Fardon R, Ciccocioppo R, Kerr TM, Smith DL, Ben Shahar O (2001). Enduring resistance to extinction of cocaine-seeking behavior induced by drug-related cues. Neuropsychopharmacology 25: 361-372.

Westerink BH, Kwint HF, deVries JB (1996). The pharmacology of mesolimbic dopamine neurons: a dual-probe microdialysis study in the ventral tegmental area and nucleus accumbens of the rat brain. J Neurosci 16: 2605-2611.

White NM, McDonald RJ (2002). Multiple parallel memory systems in the brain of the rat. Neurobiol Learn Mem 77: 125-184.

Wikler A (1973). Dynamics of drug dependence, implication of a conditioning theory for research and treatment. Arch Gen Psychiatr 28: 611-616.

Xi ZX, Baker DA, Shen H, Carson DS, Kalivas PW (2002). Group II metabotropic glutamate receptors modulate extracellular glutamate in the nucleus accumbens. J Pharmacol Exp Ther 300: $162-171$.

Xi ZX, Stein EA (2002). Blockade of ionotropic glutamatergic transmission in the ventral tegmental area reduces heroin reinforcement in rat. Psychopharmacology (Berlin) 164: 144-150.

Yokel RA (1987). Intravenous self-administration: response rates, the effects of pharmacological challenges, and drug preference. In: Bozarth MA (ed). Methods of assessing the reinforcing properties of abused drugs. Springer-Verlag: New York. pp 1-34.

Zahm DS, Brog JS (1992). On the significance of subterritories in the 'accumbens' part of the rat ventral striatum. Neuroscience 50: 751-767. 